\title{
SYSTEMIC INTERACTION OF CENTER AND REGIONS IN UKRAINE (basics of national-civilizational security)
}

The relevance of the topic, directions, and purpose of the study. The substantiation of the systemic interaction between the Center and the Regions of Ukraine provided for the consistent scientific development of the authors regarding the introduction of budget federalism in Ukraine as an independent unitary state $[1,2,3]$.

The formation of a New World Order from the beginning of the 70s of the last twentieth century, based on the predictions of the Club of Rome, acquired signs of completed international liberalism not only in capitalist countries but also in communist China, whose state capitalism ensured the presence of three companies (Sinopec Group, State Grid, and China National Petroleum) from the five largest worlds. In 2020, according to the Fortune Global 500 list, China had 124 companies against 121 in the US.

Three-quarters of Chinese companies are stateowned enterprises that occupy the "command heights" of the world economy and are led by the Communist Party under the slogan "Stronger, better, larger!". Chinese state-owned enterprises operate in the national economy's strategic sectors, from energy and shipping to rare earth mining. The total assets of China's 96 largest state-owned enterprises are more than 63 trillion dollars in the US, equivalent to nearly $80 \%$ of global GDP [4, p. 1].

At the same time, Chinese private firms and companies, relying on many subventions, industrial policy, and the domestic market (where the state limits foreign competition in strategic sectors of the national economy), have become leaders in advanced technologies in the world market. First of all, it concerns robotics, artificial intelligence, biotechnology, and telecommunications. From 1995 to 2015, the average number of the 100 largest Chinese conglomerates increased from 500 to more than 15 thousand, which means 1.5 million companies, which is only for 100 leading business groups $[4$, p. 6].
In 2020, China overcame the poverty of the population, which amounted to more than 1.4 trillion man, and his devotion to mental identity ensured the achievement of such a state of management and livelihood on the basis of its own model of planned socialist market economy, in which both public and private enterprises are only Chinese and act on the unity of only the Chinese people and state. The globally centralized US economy, a global hegemon operating on a network economy like a vampire's head, has eight tentacles, seven of which, through the G7, are launched into all sectors of the world's national economies and the private lives of Earthlings. Suckers on tentacles are levers of control of systems of management and vital activity of vassalscolonies of an octopus-vampire.

The body of an octopus-vampire - a hunter of tropical and subtropical seas and oceans - has eight tentacles and looks like a bag-shaped ball, which hides a highly developed brain and nervous system, surprisingly intelligent animal. Deciphering the genome of the octopus in 2015 was a good proof of this statement: the number of base pairs, it lags behind the human by only 400 million ( 2.7 vs. 3.1 billion).

The Group of Seven (G7) is an international club that unites the United Kingdom, Germany, Italy, Canada, France, Japan and the United States. As the G7 has no statute and it is not possible to officially obtain the status of a club member, the cooperation of club members concerns the fixing of the parties' intentions to follow an agreed line or to blindly obey other participants in international life to the demands and orders of external forces, not GENUS to the indigenous population [5].

After the conscious and purposeful collapse of the USSR, for 1991-2002 years, G7 gradually (according to the "7 + 1" scheme) was transformed into an "eight" with the participation of Russia as the successor of the USSR. Since 2014, after the annexation of Crimea to the Russian Federation, Western countries refused to participate in the work of the G8 and began to hold meetings again in the format of $\mathrm{G} 7$. 
In June 2020, US President Donald Trump made a proposal to return Russia to G8 $(7+1)$, but other member countries of the group did not support this [5].

In August 2019, after the next meeting of the heads of the G7 member states in Paris, French President Emmanuel Macron addressed the traditional annual ambassadors' conference at the Élysée Palace. In addition to French ambassadors, the conference was attended by the presidents of the G7 member countries, the prime minister, ministers, and parliamentarians of France [6].

Emmanuel Macron revealed the trends of Western hegemony in the world over the past 300 years:

- in the XVIII century - French hegemony - thanks to the Renaissance and Enlightenment;

- in the XIX century - British hegemony - thanks to the industrial revolution;

- in the XX century - American hegemony due to two world conflicts (the First and Second World Wars).

After World War II, Washington used military procurement and large research and development $(\mathrm{R} \& \mathrm{D})$ budgets to accelerate the development of advanced technologies that are the basis of the modern economy, ranging from the Internet, satellites, GPS, aircraft, vaccines, supercomputers, and smartphone components, etc. $[4$, p. 7$]$.

Recognizing the US's economic and political dominance in the world, the French President stated: "We are definitely witnessing the end of Western hegemony in the world." The report focused on India, Russia, and China's development strategies, as a kind of civilizational state whose movement is led by stronger political inspiration than what Western Europeans have.

As one of the Normandy Format members (Ukraine-Germany-France-Russia) for the restoration and preservation of peace in the Donbas, Emmanuel Macron, in his report, identified two main risk factors for geopolitical upheavals and military conflicts.

The first, in his view, is that conflicts lead to an increase in the number of civilian casualties, even when the nature of these phenomena changes.

The second point is seen in the growing savagery when the conflict parties abandon agreements on the control of weapons and their use.

Summarizing the disclosure of the role of France in Europe, Macron emphasized: "We know that civilizations are disappearing like countries. Europe will disappear with the collapse of this Western era, and the world will line up around two big poles - the United States and China. We will have a choice between dominating the two forces".

Recognizing thus the USA and China as geopolitics superpowers, the President of France draws a conclusion concerning the need of the choice of the pole by France for a big change: "Whether we will be younger allies of any given party, or it is a little of one and a little bit the second? Or we will try to play our own game and to carry out our own influence?"

Jude Blanchett, head of the Department of Chinese Studies at the Center for Strategic and International
Studies in Washington, D.C., emphasized: "Building an economic order for this century is, of course, a largescale task, but, as the recent breakdown of ties between the United States and China shows, in the absence of effective intermediary institutions, economic and financial friction can metastasize and develop into geopolitical tensions" [4, p. 8].

Ukraine should do its best to avoid the role of the red rag in the track record of trade disputes between the United States and China.

Unfortunately, as of today, Ukraine has chosen the path of the puppet doll of the world's main puppeteer in its struggle with Russia. Russophobia flourished after the Second Maidan in 2014 practically eliminated the moral and spiritual traditions of the Slavic brotherhood. Hatred and aggression of "real" Ukrainians flourish not only against "Muscovites", but also against Russianspeaking Ukrainians both in Donbass and on the territory of Ukraine. There is a leveling of historical events and a revision of the paradigm of the estate of the spiritual foundations of the nation.

Ukraine has introduced into the ranks of its own state policy a foreign ethnogeopolitical paradigm of the United States, which focuses on fascist neo-Nazism as a way to protect the private financial capital of the oligarchs.

In his report, the President of France stressed that deep financing took place in Europe and the world's modern market economy. It became the economy of accumulative capitalism, which led to a significant concentration of wealth in the hands of "champions" (oligarchs) as talented people, as well as those who have success in globalizing large metropolises and countries.

In this regard, it is appropriate to recognize that the Macron report is a remarkable example of strategic thinking and directly affects the interests of Ukraine since the initiatives of the French president on Russia are directly related to Ukraine. Moreover, they reflect a fundamental turn in large part of the European elite's views, which can have serious consequences for the World Order.

Based on a careful study of the report of the President of France Emmanuel Macron, in December 2019, an article was prepared and published "Scientific and methodological support for strategic planning and state regulation of regional human development in Ukraine" (Bulletin of Economic Science of Ukraine. 2019. № 2 (37). P. 223-237). The article presents recommendations for clarifying the current model of market economy in Ukraine based on social planning and organizing systemic interaction between the Center and the Regions in the final formation of the State Strategy for Regional Development for 2021-2027 years.

Based on the rethinking of his own 60-year experience of planned management of the national economy of the USSR, the only reasonable solution is to develop his own model of a market economy, which, following the example of France, will be based on the triptych of statehood: security, sovereignty, and influence [6]. 
In June 2020, at the Davos World Economic Forum (WEF), which was created in the 70s of the last century in Davos (Switzerland), it was stated that the current model of capitalism is outdated. It is necessary to immediately proceed to the practical implementation of the Plan of the Big Reboot (PBR) and the implementation of the fourth industrial revolution. The Davos WEF stimulated its methodological developments for many years [7].

The PBR is based on the ideas of inclusive capitalism, seemingly aimed at overcoming poverty by solving the problems of growing inequality in income and wealth. Supposedly in order to prepare proposals to mitigate the effects of the financial crisis of 2007-2009, in 2012, the Henry Jackson Society created a working group for the "Inclusive Capitalism Initiative" project with the involvement of Lynn de Rothschild, who managed EL Rothschild, as co-chairman. The company has major investments in the media (including The Economist), as well as in real estate, the business of trust asset management, infrastructure, agriculture, and the production of consumer goods. The holding's geography is the USA, Great Britain, Europe, Africa, India [7, 8].

In May 2014, Lynn de Rothschild organized a conference on inclusive capitalism in London with 250 corporate and financial leaders controlling about a third of the world's investment assets, as well as IMF head Christine Lagarde, his Royal Highness Prince Charles, former US President Bill Clinton, Lord Mayor of London Fiona Woolf [7].

In 2016, speaking in New York at a conference on inclusive capitalism, IMF head Christine Lagarde emphasized the importance of business in supporting an inclusive economy as part of an inclusive society as a whole [7].

In December 2020, with the assistance of the world's largest investment companies, business leaders, and the Vatican, called "The Guardians of the Council on Inclusive Capitalism," the Council on Inclusive Capitalism was created [7].

That is, inclusive capitalism is a "global alliance" of the Rothschilds and the Pope as an alliance of the Cross and Momona and 33 partner organizations.

Business entities that are represented in the "guardians" group have assets under management worth more than $\$ 10.5$ trillion by companies with a market capitalization of more than $\$ 2.1$ trillion and 200 million employees in 163 countries [8].

Lynn Forester de Rothschild and Pope Francis exchanged protocol courtesies. The Rothschild clan representative: "We are responding to the challenge of dad Francis to create a more inclusive economy that more equitably distributes the benefits of capitalism and allows people to fully realize their potential" [8].

Pope Francis: "An economic system that is just, credible, and capable of solving the most serious problems facing humanity and our planet is urgently needed. You accepted the challenge by looking for ways to turn capitalism into a more inclusive tool for holistic human well-being" [8].

Key figures in the Council on Inclusive Capitalism are Ms. Rothschild and the Pope. Close to their duet is the president of the Foundation Forda Walker, the president of the Rockefeller Foundation, Rajiv Shah, as well as the CEOs of the corporations' Visa, Mastercard, Bank of America, British Petroleum [9].

Among the "especially close" include Mark Carney, the UN special envoy on climate. He's not so much a climatologist as a banker. In 2000-2013 headed the Bank of Canada; in 2013-2020, he was the Bank of England's head. And in 2019, at the annual US FRS conference in the American city of Jackson Hole, with the heads of central banks of different countries and the heads of the FRS units, Mark Carney proposed replacing the dollar with the world reserve currency with a new digital currency [9].

The Council for Inclusive Capitalism's official governing body with the Vatican is a group of "guardians" consisting of 27 important people. These are all the above, and in addition: Oliver Bäte - Chairman of Allianz SE; Marc Benioff - Chairman, Chief Executive Officer and Founder of Salesforce; Edward Breen - Executive Chairman of Dupont; Kenneth Frazier - Chairman of the Board of Directors and Chief Executive Officer of Merck \& Co., Inc.; Brian Moynihan - Chairman of the Board and Chief Executive Officer of Bank of America; Deanna M. Mulligan - President and Chief Executive Officer of the American life insurance company Guardian; Ronald P. O'Hanley - President and Chief Executive Officer of State Street Corporation, etc. [9].

The "guardians" also include several responsible persons from non-business organizations: Angel Gurria, General Secretary of the Organization for Economic Cooperation and Development (OECD); Sharan Barrow General Secretary of the International Trade Union Confederation; Fiona $\mathrm{Ma}$ is the state treasurer of California. Some see the number of "guardians" equal to 27 , a mystical meaning: the Masons on the 27th degree is the "chief of the temple".

The creation of a "global alliance" by world capital is another smokescreen designed to make a "great perestroika" that will establish the domination of the superrich over the planet. The first undoubted success of the "global alliance" was marked: within a few months, they managed to put masks on billions of people, making the mask on a person's face a sign of obedience. Now they themselves can remove the mask from their activities and act openly. Then the head of the Vatican will not be needed as a "trailer" for the "global alliance".

In 2020, the Rockefeller Foundation, together with the Ford Foundation, announced the launch of the Coalition for Inclusive Capital concept - "A new agreement between business, government and American workers" [8]. 
In the current conditions of honing globalization, Tatyana Solovyova has identified the following areas of the Big Reset Plan for the period until 2030 [6]:

1. A substantial increase in taxes and Hegemon's control of the distribution of income of countries should result in the supposedly prosperous population with a focus on "Equality and Brotherhood" thanks to the reformatting of the social environment.

2. Reduction and elimination of private property, including movable and immovable property.

3. Digitalization of society, the abolition of cash due to robotization, and the introduction of artificial intelligence.

4. The transition from the "shareholder" system (with the rights of the founder, owner, or manager) to the "stákeholder" system (as an ordinary shareholder, participant, or worker). As a result of minimizing the management of their own business, the "shareholder" system will be completely eliminated as the basis for removing the middle class in favor of monopolists with large businesses.

The formation of capitalism "stákeholder" (capitalism of "participants") is focused on such a social polarization of society when $1 \%$ of the oligarchy will be ruled by $99 \%$ of poor ordinary people as secondary participants in the large commercial sector of the AngloSaxon market economy model. The form of unification of the oligarchy ( $1 \%$ ) with commoners $(99 \%)$ will be the so-called "social contracts" under the invincible slogans "Freedom and Democracy" and "Equality and Brotherhood."

According to the Big Reset Plan, the state, as obedient vassals-colonies of the United States, will act as chain dogs for the tax burden, and the ideologists will be the WEF and the UN (non-selection structures). The scheme is not new; once an entire colony of India on behalf of Britain was led by a private East Indian company. Politicians in individual countries will not be able to do anything in contradiction, and all operate according to one methodology [7].

The US world hegemony has chosen Ukraine in advance as the intended encouraging springboard for maintaining a group of G7 and unipolar dominance and preventing the restoration of bipolarity with the participation of China and Russia, as well as the USSR.2.0. The republics of the USSR (except Belarus) and most countries of the world, introducing the Anglo-Saxon model of an open-type market economy, are deployed on the axis of vassals colonies beyond their own WILL.

China's attempts to cooperate with Ukraine in Crimea in 2012-2013 regarding the construction of the most modern seaport in Feodosia with the deepening of the Black Sea Bay and the redemption of shares of the Zaporizhzhya Motor-Sich plant, which has the most modern technologies, were "diplomatically blocked" by the United States.

For its part, Ukraine, contrary to the provisions of the 1996 Declaration on State Sovereignty of Ukraine from the 16.07.1990 and Constitution of Ukraine, should become a member of NATO and the EU, carry out 62 reforms and development programs of the state to introduce European standards of life, introduce a free land market from July 2021.

In the early 90 s of the twentieth century, Ukraine was the most developed republic of the USSR and had the third nuclear potential of military weapons globally.

Institute of Cybernetics and Institute of Economics of the Academy of Sciences of the Ukrainian SSR, Economic Research Institute (ERI) and General Directorate of Research Organizations under the State Economic Council of the USSR (GDRO) the computing centers of the State Planning Commission of Ukraine were the main scientific organizations in the field of economics, organization and management of the Union republics within the USSR. These structures were also the main scientific organizations for developing scientific foundations for modeling, forecasting, and national economic planning in creating sectoral and territorial ACS of various scales of economic and vital activities and Automated Planning and Financing Systems at the republic level.

In 1994, ERI, having 30 years of experience in cooperation with the State Planning Commission of the Ukrainian SSR, the State Planning Commission of the USSR, and the State Plans of the Union Republics, initiated a proposal regarding Ukraine's membership not only in the UN but also in the UN Security Council as a country significantly damaged during the Great Patriotic War and the Chernobyl accident. But the slogans "Plan - out!" and "Freedom to market relations!" crossed out the efforts of ERI to combine the Plan and the Market to relieve the geopolitical tensions of the unipolar world $[10,11]$.

The global centralized economy of the United States, as the head of the vampire octopus, constantly releases well-planned distracting ink stains - the slogans "Freedom and Democracy" and "Equality and Brotherhood" - to continue maintaining its unipolar dominance in the world. These ink stains serve as a trigger and a false goal of color revolutions and reshaping the world, in particular the creation of the Greater Middle East (consisting of Arab countries and Azerbaijan, Afghanistan, Iran); the secession of Crimea and Donbas from Ukraine and their accession to Turkey by 2050 or the creation of Israel 2.0 for its temporary shelter in the Crimea and Donbas and the south-eastern part of Ukraine in the event of World War III. Schemes for reshaping the world are developed by US special intelligence services in advance, 10-15-20 years before the events.

US Secretary of State Antony Blinken said they were disappointed in the color revolutions. For a long time, Washington dropped regimes in other countries in order to "promote democracy," which is too expensive for the state budget and does not guarantee success. "We will not promote democracy through expensive military operations or the overthrow of authoritarian regimes by force. We tried such tactics in the past, and it did not work. However, the United States has not completely 
abandoned the very idea of forming foreign governments "under itself" [12].

Antony Blinken emphasizes that US President Joe Biden's administration will do this differently - not through revolutions but through "inducement to reform" with the help of forced loans.

Anthony Blinken emphasizes that the administration of US President Joe Biden will do it differently not because of revolutions, but because of "incentives for reform" through forced loans. The European Union and the IMF have already obliged Kiev to reform public authorities, raise tariffs for the population, lift the ban on land sales and create a number of anti-corruption bodies through which the West exercises external control and governance over Ukraine. The state and the population are mired in excessive loans from the IMF.

The mechanism of unipolar domination of the United States is provided by transnational corporations, whose financial resources are several orders of magnitude higher than many countries' national budgets. This mechanism is implemented by the logistics of the International Geopolitical Business, which contributes to the selection and appointment of "convenient" presidents, prime ministers, ambassadors, members of the judiciary, heads of ministries, departments, regions, law enforcement agencies, intelligence and defense, and anticorruption services.

The use of the Anglo-Saxon model of an open market economy leads to the emergence of international terrorism, the main goals of which are "disorganization of public administration, economic and political damage, violation of the foundations of the public apparatus, which, in the opinion of terrorists, should motivate the authorities to change politics" [13].

The main signs of international terrorism are globalization, professionalization, and reliance on extremist ideology. At the same time, there is a threat to the use of non-conventional weapons: nuclear, chemical, and bacteriological (in particular, the COVID-19 pandemic) [13].

UN Security Council Resolution No. 1373 of September 28, 2001, notes "a rather close connection between international terrorism and transnational organized crime, illegal drugs, money laundering, illegal arms sales and illegal transportation of nuclear, chemical, biological and other potentially dangerous materials". Experts also note the increase in the technical equipment of terrorists and their tacit support from certain states [14].

State terrorism has signs: poverty and constant fear of the population, lack of democratic freedoms, intimidation of the population and authorities, violent acts against certain categories of citizens, failure of power, and the desire for power through latent terrorism (primarily the killing of state leaders, scientists, cultural figures, literature, and art) [14].

International terrorism against the brotherly Slavic peoples of Belarus, Russia and Ukraine has managed to break the Treaty of Friendship and Cooperation between
Ukraine and the Russian Federation, leading to state violence against the population, which has no legislative or judicial support and can be practiced by state law enforcement agencies. The actions of state terrorism are carefully concealed, an example of which is the signing on April 14, 2014 under the label "secretly" of the Acting President of Ukraine, Chairman of the Verkhovna Rada of Ukraine O. Turchynov of Decree № 405/ 2014 "On the decision of the National Security and Defense Council of Ukraine of April 13, 2014 «On urgent measures to overcome the terrorist threat and preserve territorial integrity of Ukraine»".

Volunteer punitive battalions, financed by oligarchs, were sent to the Ukrainian Donbass (according to the logistics of the International Geopolitical Business), joined by the regular armed forces of Ukraine in violation of the Constitution of Ukraine on the impossibility of using them against their own people.

The mission of the Ukrainian Donbass is to preserve the commandments of the Slavic peoples to protect their land and subsoil, their language and faith, culture and traditions of the GENUS, the historical values of peace and good, its victory over evil.

In the current conditions of deepening the liberalization of the Ukraine market economy by the national authorities, there was a need to understand and strengthen the Ukrainians' own national idea as citizens of our state - to be a master in their native land.

It was overdue to clarify, preserve and develop a system of national values, which is designed to ensure the diversity of individual characteristics of the population of each region of the state: spirituality and education, customs and traditions, culture and worldview, peaceful mentality, and territorial unity, historical heritage and ethnic values.

The existence of stable moral traditions of interaction between the center and the territories are designed to contribute to the emergence of mutually agreed emergent development of all state regions as a single organic and dynamic whole.

An alternative option to the Decree on the ATO opening could be a solution for the transition of Ukraine (as an unified state) to the model of budgetary federalism, with the establishment of financial standards for budgetary security of the main warehouse social and economic (including human) development in Lugansk and Donetsk regions. At that hour before the warehouse of financial standards of budgetary security, when planning the views of the budget, there were offensive warehouses: state management; education; protection of health; social security i social security; culture i mystery; physical culture i sport.

In 2011, the Scientific and Practical Commentary on the Budget Code of Ukraine updated in 2010 [13] proposed the additional inclusion of financial standards for the budgetary provision of guaranteed services of housing and communal services and the media (by order of the Ministry of Finance of Ukraine, responsible pro- 
ject executor, scientific editor, doctor of economic sciences, professor V. F. Stolyarov).

The head of a similar Scientific and Practical Commentary on the Budget Code of Ukraine in 2000 was directly A.V. Turchinov as a deputy of the Verkhovna Rada of Ukraine, the head of the corresponding Committee and the Working Group for the Development of the Budget Code. That is, he personally and his assistants are sure to be acquainted with the new version of the Scientific and Practical Commentary on the 2010 Budget Code of Ukraine. $\mathrm{n}$ addition, as the chairman of the Verkhovna Rada of Ukraine, Turchinov knew about the draft Law of Ukraine "On Amending the Budget Code of Ukraine (regarding increasing the financial independence of the Autonomous Republic of Crimea and Sevastopol)," which was adopted 15.04.2014 with his participation and provided for:

- credited in full to the budget of the Autonomous Republic of Crimea all revenues that are paid (overpaid) on the territory of the Autonomous Republic of Crimea and the city of Sevastopol;

- granting the right of local authorities to determine the cost of lending the budget within the revenue without applying leveling mechanisms, that is, without state intervention in the process of forming the budget of the Autonomous Republic of Crimea and the city of Sevastopol;

- the possibility of distribution of inter-budget transfers between the budget of the Autonomous Republic of Crimea, the city budget of Sevastopol and the relevant local budgets.

Considering changes, the Autonomous Republic of Crimea and Sevastopol's budgets became balanced in terms of revenue and expenditure parts without a deficit (with zero transfer from the state budget).

That is if the annexation of the Autonomous Republic of Crimea and the city of Sevastopol territory at the time of the adoption of the Decree Acting President of Ukraine 14.03.2014 even before the start of the ATO, and starting from 18.03.2014, the work of the tax and treasury services on the Ukrainian peninsula was blocked, then cooperation with such services of the Lugansk and Donetsk regions was still possible.

Provisions of the Law of Ukraine dated 15.04.2014 in the sphere of financial and budgetary policy and increasing the financial independence and autonomy of the Autonomous Republic of Crimea and Sevastopol; it would be advisable to extend the formation of local budgets of the Lugansk and Donetsk regions in the negotiations of Kiev national authorities with the initiators of the creation of People's Republics within the then regional and local authorities.

The same could be envisaged in the events of 2015 to implement the Minsk Agreements of August 2014.

The preservation of the territorial unity of Ukraine on our proposals provided for the extension of the initial provisions of the budget federalism of Ukraine as a unitary state not only to Lugansk and Donetsk regions but also to the remaining 22 administrative regions, which, since 1999, have been subsidized. So, if in 1996, only 11 regions were subsidized, then in 1997-1998 their number increased to 22, that is in 2 times.

After the Dignity Revolution, government decisions regarding the Lugansk and Donetsk regions were prepared on falsified information. So, for 13 years of statistical observations by the State Statistics Service of Ukraine (1999-2012), these regions among 27 administrative-territorial units of the republic (24 regions, Crimea, Kiev, and Sevastopol) constantly took 26th and 27th places in the rating of the Regional Human Development Index (RHDI) on a single scale of its measurement.

But in the "State Strategy for Regional Development for the Period until 2020," approved by the Government Decree of 06.08.2014. No. 385 (signed by A. Yatsenyuk) places in the ranking of the RHDI of the Lugansk and Donetsk regions are not mentioned. On the contrary, complaints have been made about higher wages compared to other regions of the state without considering the terrible ecology and unbearable working conditions and their contribution to the country's GDP.

The numerical and graphical data on RHDI of the Ukrainian regions given in the "State Strategy for Regional Development for the Period until 2020" are presented for 2011-2012 without the initial data of the Lugansk and Donetsk regions. However, as of August 2014, this could be carried out according to statistics from 2013. In addition, to improve the "type" of Ukraine according to the world dimension of the Human Development Index (HDI), 2012 data are presented according to the results of 2013 (the year of the Second Maidan) because Ukraine in the UN World Ranking showed a decrease in the ranking by 5 positions (from 78 to 83 places).

The cynical populism, dormancy, and primitiveness of the thinking of ex-Prime Minister of Ukraine V. Groysman can be considered the government decision of 2017 to plan Ukraine to enter the HDI in the 50 best countries of the world in 2020 against 88 places in 2017 (Government Order of 03.042017 No. 275-r). That is, in 3 years, it was necessary to "defeat" 38 places - from 88 to 50 - about 13 positions each year. This is bureaucratic insanity!

The anti-terrorist operation (ATO) against the population of Luhansk and Donetsk people's republics of the Ukrainian Donbass, which were established on May 12 and 24, 2014, was launched on the eve of the early elections of Petro Poroshenko on May 25, 2014 to the position of President of Ukraine. It seems that the antiterrorist operation was launched in order to prevent the population of the Ukrainian Donbass from holding early elections of the President of Ukraine.

Under the auspices of the secret Decree № 405/ 2014, a civil-armed conflict between the Regions and the Center was organized, and then the Financial Fund of many partners was created to eliminate its consequences. The oligarchs and big business of the Liberal Democrats of the United States, leading members of the 
European Union, Russia and Ukraine have shown themselves to be components of international terrorism against the people of their countries. This arose from the nature of profit and violence through the use of the Anglo-Saxon model of an open market economy.

Military conflicts begin rich as a system of defense of their interests, sending to the death of the children of ordinary people; civil and interstate wars are taking place in all countries of the world as a business on blood. It's just awful!

The impetus for the Center's civil-military conflict with the authorities and the population of the Ukrainian Donbass (February-March 2014) was the natural rejection by the national mentality of dishonest enrichment of those involved in the government and deliberate disregard for social justice and administrative responsibility for corruption. Accelerated and forced (contrary to evolutionary) Ukrainization of the Russian-speaking population, its material impoverishment and humiliation of human dignity and the destruction of the historical past became the moral and spiritual basis of the Regions' protest against the Center (Kiev). The center, having adopted the paradigm of cunning, presents the world community with this conflict as a war with Russiaaggressor.

The Center neglected the opportunity to hold a dialogue with the initiators of the people's republics and residents of the regions during April-May 2014. It was necessary to urgently discuss and outline the development of Regional Human Development Programs of Luhansk and Donetsk regions and their implementation within the budget federalism of the unitary state. Methodological support for the implementation of these intentions was developed in 2011 by the National Academy of Financial Management and the Ukrainian University of Finance and International Trade, and the procedure for developing Regional Human Development Programs was contained in the Scientific and Practical Commentary to the Budget Code of Ukraine.

The people's exit from depression and the state from degradation are seen in the implementation of a human-centric approach to organizing the Regions and the Center's systemic interaction. The draft State Strategy for Regional Development for 2021-2027 has already been developed under the slogan "Human-centred development and unity." This slogan was the first of the 3 components of the goal of the strategic direction of the State regional policy for the period until 2020 but was never implemented.

The main areas of research on the Center and the Regions strategy of Ukraine were:

- consideration of the organization of interaction between the Center and the Regions in the development of State and regional development strategies;

- identification of regional human development trends in administrative areas using national measurement techniques;

- assessment of the prerequisites for the formation of budgetary federalism of the unitary state;
- revealing the possibilities of using the harmonious proportions of the "Golden Section" to achieve the balance of state and local budgets in the Consolidated Budget of Ukraine.

According to the main directions of the study, the main goal was to identify organizational shortcomings and managerial shortcomings in the strategy of the Center and the Regions for the periods until 2015, 2020, and 2027 and substantiate recommendations and proposals for their elimination in the context of ensuring national security of the state.

Setting the problem of strategy and new management of system interaction of the Center and Regions. It is appropriate to justify the new management of the system interaction of the Center and the Regions from the point of view of revising the open market economy model in Ukraine by introducing the doctrine of 3 "S": social forecasting, social planning, and social management.

The term "Social Planning" was first used by Franklin Delano Roosevelt when justifying the ways in which the United States left the Great Depression. Subsequently, in American sociology, this concept was analyzed in close connection with the forms and methods of implementing social policy and ensuring social protection of the population [16].

After World War II, in the developed west countries, social planning began to be used already as an instrument of state regulation of socio-economic development and planned systemic formation. First in France, which developed the first five-year plan for 1947-1953 (Monnet Plan), and then in Holland, Great Britain, Germany, Italy, Japan, and elsewhere in the world [17].

Independent Ukraine, on the contrary, has abandoned its own 60-year experience of centralized planned management of the national economy. Almost all scientists and specialists in planned economics believed that the plan was a law for mandatory execution, and it was necessary to bear both social and administrative responsibility for errors in planning.

At various stages of the United States' formation as a world leader in the freedom and prosperity of the American people, such a form of capitalism as popular, and overtime - as inclusive, has acquired relevance. The United States' domestic experience is also becoming useful for Ukraine, especially when considering the principles of systemic interaction between the Center and the Regions in the context of the introduction of budgetary federalism of the unitary state.

In the mid-1950s, "popular capitalism," as a successful American economic system, was approved by US President Dwight Eisenhower as a propaganda advertisement for achievements during the Cold War. The US News Agency used it at fairs, reflecting the United States as a classless society of prosperous American workers, unlike the "slaves" of the USSR and China.

One of the varieties of a popular capitalism was recognized as the Employee Stock Ownership Plan (ESOP) in their own enterprises, which was widely used 
in the UK under Margaret Thatcher. But when implementing the Transport Act in 1985, which aimed to deregulate and privatize municipal enterprises, their shareholders lost shares in the processes of their mergers and acquisitions [18].

At the same time, the features of the European model of financial participation of employees of enterprises (participation in profits; share of ownership of the enterprise; ownership of shares) are advisable to use to correct the current Anglo-Saxon model of the open market model in Ukraine.

In 2005-2006, the Ukraine Government decided to localize the Millennium Development Goals (MDGs) for the period until 2015 as pilot projects for the Ukrainian Donbas as part of the Lugansk and Donetsk regions and the Lviv region.

The pilot projects were designed to adapt 15 national targets and 33 strategic indicators of the 7 MDGs [19]:

1) overcoming poverty ( 3 tasks and 5 indicators);

2) ensuring quality education during life (2 tasks and 6 indicators);

3 ) ensuring gender equality ( 2 tasks and 4 indicators); tors);

4) reduction of child mortality ( 1 task and 2 indicators);

5) improving maternal health ( 1 task and 2 indica-

6) limiting the spread of HIV/AIDS and tuberculosis and starting trends towards their reduction ( 2 tasks and 6 indicators);

7) sustainable development of the environment (4 tasks and 8 indicators).

The achievement of the MDGs by 2015, both on pilot projects and Ukraine as a whole, was recognized as essential for consolidating the efforts of three components of society: government, business, and the public. But that didn't happen.

It should also be emphasized that it was not accidental to "Overcoming poverty" as one of the 7 national MDGs. If the bodies of national and regional authorities on the basis of socially adequate management ensured its phased achievement since 2003, then we assume that there were no grounds for the conflict in 2014 of the Center with the Ukrainian Donbas.

Again, among the national targets of the 17 Sustainable Development Goals (SDGs), as well as among the national targets of the 7 MDGs, the goal "Overcoming poverty" ( 3 targets and 5 indicators) has been defined in the first city of Ukraine. The situation in Ukraine requires maintaining a targeted orientation of human development in the transition from the implementation of the MDGs for the period up to 2015 to the achievement of the CSR for the period up to 2030 [20].

Thanks to the implementation of the pilot project "Lviv Region-MDGs," in the Regional Development Strategy for the period 2020, updated in 2014-2015, and in the Action Plan for its implementation for 2016-2018, Program 2 "Quality of Life" appeared, which included
18 strategic indicators of sustainable human development. In addition, according to the Act of 8 September 2005 on the promotion of regional development (which entered into force on 1 January 2006), the Lviv ODA and the Regional Council concluded an agreement with the Cabinet of Ministers on the implementation of the Action Plan in accordance with State priorities for the development of the region.

Unfortunately, this did not happen in the Ukrainian Donbas. The pilot projects' objectives, "LuganshchinaMDGs" and "Donetchina-MDGs," were not envisaged either in the Programs and Budgets of socio-economic development Lugansk and Donetsk regions or in the national plan and the state budget for 2006-2010 years.

The government could not organize the generalization and dissemination of the Lviv region's positive experience to the Lugansk and the Donetsk regions and the rest of Ukraine.

In 2007, on the eve of the global financial crisis of 2008-2009, the initiator of the creation of the Economic Council of the Cabinet of Ukraine (vice-chairman) and the State Duma of Ukraine (chairman of Economic board) Dr.Econ.Sci., professor, the correspondent member NAS of Ukraine Oleksandr Sergijovych Jemeljanov justified the increase in the role of the state in the development of the economy, considering it appropriate:

- regulate the State Program of Economic and Social Development of Ukraine by the highest State decision as a plan of action of government structures at the functional, sectoral, and regional levels to involve market economy entities in the implementation of national goals declared by the President of Ukraine;

- such a program should contain planned guidelines and tasks for the formation of macroeconomic indicators, basic generalized and synthesizing indicators, as well as participation in their formation of industries and regions;

- to oblige ministries, departments, and regional administrations to develop annually, on the basis of the priorities and tasks of the State Program, its relevant sectoral and regional sections.

When developing the State Program, its sectoral and regional sections, it is necessary, in his opinion, to provide, first of all, for the provision of priority areas of development with sources and volumes of financing, appropriate labor resources, and when implementing it to attract private enterprises and investors.

Oleksandr Sergijovych Jemeljanov proposed the creation of branch divisions in the Ministry of Economic Development of Ukraine and its research institutes, entrusting them with forecasting and analytical work and the formation of tasks for branch divisions of the program as the basis for the formation of state orders.

Jemeljanov realized that some officials and their supporters would take a position on strengthening the role of the state in the development of the economy extremely negatively. Some - due to illiteracy and fetish market slogans, others - under various consultants and their chefs' dictation. The main argument at the same 
time, all as one, will put forward the thesis that there is a "return," "restoration" of the planned economy. Therefore, at the end, he emphasized: "Dear colleagues! Do not be afraid of the market, and therefore do not be afraid of public administration" [21, p. 59].

Memoirs and analytical memoirs of Oleksandr Jemeljanov in 2012 are given still big relevance after acceptance 03.11 .2011 by the Verkhovna Rada of Ukraine in the first reading of bill No. 9407 "About the state strategic planning." For the adoption of the corresponding decision, 249 people's deputies voted out of the minimum necessary 226. But the final version of the law has not been adopted to this day.

State regulation of regional human development in Ukraine is made possible by the existing possibilities of using RHDI as a criterion for the effectiveness of State socio-economic, investment, regional and environmental policies. This will ensure the achievement of uniform social standards and norms of the Ukrainian people's lives throughout the territory of a sovereign and independent state.

Organization of development for 3-5 and 10-year terms (with variable base) The National and Regional Human Development Programs will become an organic component of socially adequate management of coordination of medium-term priority action plans and medium-term state and local budgets with the tasks of the State and Regional Development Strategies for 20212027 and 2024-2030 years, as well as Action Plans for their implementation in 2021-2023, 2024-2027 and 2028-2030 years.

The National Human Development Programme proposes to include nationwide targeted programs and investment projects adopted in the Socio-Economic Development Programmes since 2001 (in terms of status and levels of underfunding) and those scheduled to be implemented by 2027 and 2030. These programs and projects should become systemically important in shaping the pre-centrality of the economies of the regions to the national economy.

The Ukrainian oligarchs can carry out financing of the National Human Development Program (in speech E. Macron lovingly called them "champions" of business) and large international and domestic business on the principles of social partnership with the state using social bonds (significant experience accumulated in the UK).

Regional human development programs are recommended under sub programs that adequately define six RHDI measurement segments using 33 indicator indicators based on 33 indicators since 2004 [22]:

1) "Population reproduction" (5 indicators, 4 development stimulants, 1 dissimulator);

2) "Social environment" (6 indicators - dissimulators of development);

3) "Comfortable life" (6 indicators - development stimulants);

4) "Well-being" (5 indicators, 4 development stimulants, 1 destimulator);
5) "Decent work" (6 indicators, 3 development stimulants, 3 development dissimulators);

6) "Education" (5 indicators of development stimulants).

The strategic priorities of the socio-economic development of the state and regions under the slogan "Systematic human development to Ukrainians" can be determined based on the analysis of the trends of the components of the HDI and RHDI for the period from 1999 and from 2004, their forecast and design values as strategic indicators for the period up to 2027 and social visions by experts for the period up to 2030 .

The justification of strategic and operational goals, targets, and indicators of socio-economic development will be carried out by determining the level of HDI and RHDI desired by social standards. As a result, the State Strategy and National Priority Action Plans, Regional Strategies, and Action Plans for their implementation up to 2027 and 2030 will be based on sustainable human development. It will be based on the inalienable human rights to life and full development in economic, social, and environmental dimensions.

Of course, this will be done in accordance with social standards and norms, analogs and standards in the European Union member countries, and the expected prediction of the dynamics of their components within the corresponding material and financial resources (from the point of view of reducing the negative dynamics and level of 11 indicators-dissimulators of human development and increasing the positive dynamics and level of 22 indicators of stimulants of human development).

On the basis of the human-centric approach of the future State, it is advisable to envisage the development of a State strategy for balanced socio-economic development of Ukraine and a national plan of action to achieve the objectives of the Sustainable Development Goals for the periods up to 2027 and 2030.

The focus on the human-centric approach will ensure the finalization and implementation of the State strategy of national reforms on the main components of human development - education, health care, social assistance, and protection of the population, which will help accelerate the establishment and development of peace in the eastern regions of Ukraine.

Based on the briefly considered characteristics and directions of solving the problem on the subject and object of analytical research, he plans to substantiate the possibilities and advisability of using the Methodology for Measuring Regional Human Development of 2012 for strategic planning of human development in the regions of Ukraine in line with the adapted national goals for achieving the Sustainable Development Goals for the period up to 2030 .

The achievement of the stated plan will contribute to the definition of measures to clarify the corruption model of the Ukrainian version of the Anglo-Saxon variant of a market economy to the model of a sociallyoriented market economy in accordance with the provi- 
sions of the Declaration on State Sovereignty of Ukraine (1990) and the Constitution of Ukraine (1996) following the example of the People's Republic of China and Sweden, which built market socialism and became part of the developed countries of the world.

On the contrary, Ukraine, having proclaimed the way to build a socially-oriented market economy, actually went along the liberal-capitalist path, which led to the social stratification of the population, and in the Ukrainian Donbas - to social expansion (demarcation of population groups with unequal opportunities); social mimicry (concealment for the survival of a true system of value orientations and true intentions); social polarization (high level of economic and social inequality) [16, p. 340, 341, 343].

The problems of strategic management of the Center and Regions of Ukraine are the absence of the Planned Code of Ukraine along with Budget and Tax. The planning code should be based on the provisions of Socio-adequate management and include regulations for the development of development strategies: long-term (for 21-28 years); promising (for 14-21 years); mediumterm (7-14 years); short-term (3-7 years).

The action plans for the implementation of the Development Strategies will consist of phases in 3 and 4 years.

The Planning Code of Ukraine should also include regulations for the development of annual Messages of the President of Ukraine to the Verkhovna Rada in accordance with the Program of the President for 5 years. The same goes for the Government's Action Plan and its Reports to the Verkhovna Rada of Ukraine as a parliamentary-presidential republic.

The Planning Code of Ukraine will determine the rights and responsibilities of the Central and Regional Executive Bodies and persons for the validity and nonimplementation of state decisions on their completeness and time. It is also necessary to develop Methodological Support, supported by legal norms in the context of social, administrative, and criminal responsibility for the preparation and implementation of state decisions.

Socio-adequate management, according to the encyclopedia, is a highly effective model of management that is oriented towards the future, adapted to function in a specific social system with maximum use of its socio-economic and psycho-cultural potentials, and serves as an instrument for harmonizing the management efforts of national and regional authorities [16].

Such a model directs management influences mainly to self-organizational processes, at all levels of management correlates with the most important mental characteristics of society and its regional components.

The adequacy of social governance should be assessed at the national level according to the following main criteria [16]:

- the ability of the management system to strike and maintain a balance between the dominant goals of society and the ways in which they are achieved;

- an open social structure;
- adequacy of management of national character;

- the ability to create a social and economic order that ensures the normal existence of a social organism;

- conformity of the management methods used with the main mechanism for the realization of power relations;

- constructively of influence on social stratification processes.

At the regional level, management will be considered socially adequate if it is capable of [16]:

- to resolve the contradictions between best market management practices and outdated management mechanisms in the territory under its jurisdiction;

- ensure the objectivity, completeness and speed of circulating information between different levels of government and regulation;

- rational organization of the management apparatus and management work;

- inclusion of social demands and views in management decision-making and implementation processes;

- ensure professional competence, and responsibility of managers in social dialogues.

Socially adequate management can be effective only if it is adequate for the goals and objectives of social development and social theory and practice of Ukraine. Strategizing the interaction of the Center and the Regions as a single organic, dynamic and integral system based on the harmonious proportions of the "Golden Ratio" in the balance of state and local parts of the consolidated budget, will provide a goodness image of a free independent republic - crown Ukraine.

\section{References}

1. Stoliarova, V., Ovcharenko, T., Kalashnikova, L. (2019). Stanovlennia biudzhetnoho federalizmu v Ukraini ta osoblyvosti suchasnoho Donbasu [Formation of budget federalism in Ukraine and features of modern Donbass]. Ekonomichnyi Visnyk Donbasu - Economic Herald of the Donbas, 3(57), pp. 89-102. doi: 10.12958/1817-37722019-3(57)-89-102 [in Ukrainian].

2. Stolyarov, V., Shinkaryuk, O., Stolyarova, V. (2019). Conceptual Provisions of Budget Federalism in the Unitary State Ukraine. Ekonomichnyi Visnyk Donbasu Economic Herald of the Donbas, 4(58), pp. 106-110. doi: 10.12958/1817-3772- 2019-4(58)-106-110 [in English].

3. Stolyarov, V. F., Shinkaryuk, A. V., Ostrovetsky, V. V., Stolyarova, V. V. (2020). Metodolohichni zasady fiskalnoi detsentralizatsii dokhodiv $\mathrm{v}$ umovakh stanovlennia biudzhetnoi federalizatsii unitarnoi derzhavy. Visnyk ekonomichnoi nauky Ukrainy, 1 (38), pp. 202-218. doi: 10.37405/1729-7206.2020.1(38).202-218 [in Ukrainian].

4. Chinese state capitalism - a threat to the US and the world. Retrieved from https://kontinentusa.com/ kitayskii-gosudarstvennyi-kapitalism-ugroza-dlya-usa-ivsego-mira/ [Accessed 6 December 2020] [in Russian].

5. Wikipedia. (2020). Group of Seven. Retrieved from https://ru.wikipedia.org/wiki/Большая_семёрка [Accessed 11 December 2020] [in Russian]. 
6. Emmanuel Macron's speech at the meeting of French ambassadors. Retrieved from https://hvylya.net/ analytics/geopolitics/vystuplenie-jemmanujelja-makronana-soveshhanii-francuzskih-poslov.html [Accessed 1 September 2019] [in Russian].

7. The Great Reset. Fourth Industrial Revolution. Where we all go. Retrieved from https://solovyeva. livejournal.com/344413.html [Accessed 17 November 2020] [in Russian].

8. Wikipedia. (2020). Inclusive capitalism. Retrieved from https://ru.wikipedia.org/wiki/Инклюзивный_капитализм [Accessed 11 December 2020] [in Russian].

9. So-called inclusive capitalism - a joint project of the Rothschilds and the Pope. Retrieved from https: //www.fondsk.ru/news/2020/12/24/tak-nazyvaemyj-inklju zivnyj-kapitalizm-sovmestnyj-proekt-rotshildov-i-papy-ri mskogo-52541.html [Accessed 12 December 2020] [in Russian].

10. Stolyarov, V. F., Shinkaryuk, O. V. (2014). Leading components of the mechanism of public administration "Life in a new way" (in the context of decentralization). Visnyk ekonomichnoi nauky Ukrainy, 2 (26), pp. 131-140 [in Ukrainian].

11. Stolyarov, V. F., Shinkaryuk, O. V. (2014). Naukovo-osvitnie zabezpechennia mekhanizmu derzhavnoho upravlinnia «Zhyttia po-novomu» (v konteksti detsentralizatsii) [Scientific and educational maintenance of the mechanism of public administration «new life» (in the conditions of decentralization)]. Visnyk ekonomichnoi nauky Ukrainy, 3 (27), pp. 113-126 [in Ukrainian].

12. "We won't be anymore": US disappointed in color revolutions. Retrieved from https://tsargrad.tv/news/mybolshe-ne-budem-ssha-razocharovalis-v-cvetnyh-revoljuci jah_329153 [Accessed 3 December 2020] [in Russian].

13. International terrorism. Retrieved from https: //uk.wikipedia.org/wiki/Tероризм\#Міжнародний_теро ризм [Accessed 19 December 2020] [in Ukrainian].

14. State terrorism. Retrieved from https://uk.wikipedia.org/wiki/ Державний_тероризм [Accessed 4 December 2020] [in Ukrainian].

15. Yaroshenko, F. O. (2011). The Budget Code of Ukraine: a scientific-practical commentary / edited Stoljarov V. F. Ukrainian State University of Finance and International Trade. 560 p. [in Ukrainian].

16. Gorodjanenko, V. G. (2008). Sociological Encyclopedia. 456 p. [in Ukrainian].

17. Mochernyi, S. V. (Eds.). (1995). Economic Dictionary Directory. Kyiv, Femna [in Ukrainian].

18. Employee stock ownership. Retrieved from https://ru.wikipedia.org/wiki/Акционерная_собственно сть_работников [in Russian].

19. Tsili rozvytku tysiacholittia «Ukraina - 2010». Natsionalna dopovid [Millennium Development Goals Ukraine 2010. National report]. (2010). Kyiv, Ministry of Economy of Ukraine [in Ukrainian].

20. Tsili Staloho Rozvytku: Ukraina [Sustainable Development Goals: Ukraine]. (2017). Ministry of Economic Development and Trade of Ukraine [in Ukrainian].

21. Yemelyanov, O. S. (2012). Osobysto prychetnyi ... Rynok Ukrainy: Istoriia ta problemy formuvannia u publikatsiiakh, naukovykh ta ofitsiinykh zvitakh avtora. 2nd edition, add. Kyiv, NDEI. 576 p. [in Ukrainian].
22. Metodyka vymiriuvannia rehionalnoho liudskoho rozvytku: Rishennia Prezydii NAN Ukrainy ta kolehii Derzhavnoi sluzhby statystyky Ukrainy vid 13.06.2012 № 123-m [Methods of measuring regional human development: Decision of the Presidium of the NAS of Ukraine and the collegium of the State Statistics Service of Ukraine dated 13.06.2012 No. 123-m]. Retrieved from http: //www.ukrstat.gov.ua/druk/publicat/kat_u/2018/zb/09/zb_ rlr2017_pdf.pdf [in Ukrainian].

Столяров В. Ф., Шинкарюк О. В., Столярова В. В. Системна взаємодія Центру і Регіонів України (основи національно-цивілізаційної безпеки)

У статті поставлена і вирішена проблема досягнення узгодженої взаємодії Центру і Регіонів як єдиної, органічної і динамічної системи суверенної самостійної держави. Розглянуті сучасні підходи ліберальних і планових принципів виходу з чиновницько-корупційного свавілля та термінова реанімація з інтенсивним відродженням господарської та життєвої діяльності України, яка цілеспрямовано руйнується під зовнішнім впливом.

Розкрито основні положення доповіді Президента Франції Еммануеля Макрона в серпні 2019 року щодо Великого перелому у Європейських і світових цивілізаційних процесах. Представлено основні ідеї і напрями Плану Великого Перезавантаження та здійснення четвертої промислової революції червня 2020 року Давоського Всесвітнього Економічного Форуму.

Наведена змістовна хронологія формування організаційного механізму впровадження інклюзивного капіталізму, його керівного і кадрового забезпечення. Розглянуто рівнозначність принципів гомеостазу економічних і біологічних систем шляхом зіставлення відновлення живучості світової мережевої економіки i морських біологічних систем (на прикладі спрутавампіра).

Узагальнено ознаки міжнародного та державного тероризму в Україні. Обгрунтовано необхідність зміни англосаксонської моделі ринкової економіки відкритого типу на соціально-орієнтовану з використанням доктрини трьох "C": соціальне прогнозування, соціальне планування і соціальне управління. Запропоновано використати досвіду США і Великобританії стосовно соціального планування і європейської фінансової моделі народного капіталізму.

На основі пропозицій О. С. Смельянова щодо підвищення ролі Центру у взаємодії з Регіонами рекомендується розробляти Національну і Регіональні програми людського розвитку. Пропонується розробити Плановий кодекс України на положеннях моделі соціально-адекватного менеджменту з енциклопедичними критеріями їх використання на національному та регіональних рівнях державного управління.

Ключові слова: менеджмент стратегування, ліберальна і планова економіка, народний і інклюзивний капіталізм, міжнародний та державний тероризм, бюджетний федералізм, регіональний людський розвиток, геополітична напруженість, спрут-вампір, гегемон свободи. 
Stolyarov V., Shinkaryuk O., Stolyarova V. Systemic Interaction of Center and Regions in Ukraine (basics of national-civilizational security)

The article poses and solves the problem of achieving coordinated interaction between the Center and the Regions as a single, organic and dynamic system of a sovereign independent state. Modern approaches of liberal and planned principles of overcoming bureaucratic and corrupt arbitrariness and urgent resuscitation with intensive revival of economic and vital activity of Ukraine, which is purposefully destroyed under external influence, are considered.

The main provisions of the report of the President of France Emmanuel Macron in August 2019 on the Great Fracture in European and world civilization processes are revealed. The main ideas and directions of the Plan of the Great Reset and implementation of the fourth industrial revolution of June 2020 of the Davos World Economic Forum are presented.

A meaningful chronology of the formation of the organizational mechanism for the introduction of inclusive capitalism and its management and staffing is given. The equivalence of the principles of homeostasis of economic and biological systems is considered by comparing the restoration of the viability of the global network economy and marine biological systems (on the example of a vampire octopus).

Generalized signs of international and state terrorism in Ukraine. The necessity to change the Anglo-Saxon model of open market economy to socially oriented one using the doctrine of 3 "S": social forecasting, social planning and social management is substantiated. It is proposed to use the experience of the United States and Great Britain on social planning and the European financial model of people's capitalism.

Based on the proposals of Emelyanov O.S. to enhance the role of the Center in cooperation with the Regions, it is recommended to develop National and Regional Human Development Programs. It is proposed to develop a Planning Code of Ukraine based on the provisions of the model of socially adequate management with encyclopedic criteria for their use at the national and regional levels of government.

Keywords: strategic management, liberal and planned economy, people's and inclusive capitalism, international and state terrorism, budget federalism, regional human development, geopolitical tensions, octopus-vampire, hegemon of freedom.

Столяров В. Ф., Шинкарюк А. В., Столярова В. В. Системное взаимодействие Центра и Регионов Украины (основы национально-цивилизационной безопасности)
В статье поставлена и решена проблема достижения согласованного взаимодействия Центра и Регионов как единой, органической и динамической системы суверенного самостоятельного государства. Рассмотрены современные подходы либеральных и плановых принципов выхода из чиновничье-коррупционного произвола и срочная реанимация с интенсивным возрождением хозяйственной деятельности и человеческой жизни в Украине, которая целенаправленно разрушается под внешним воздействием.

Раскрыты основные положения доклада Президента Франции Эммануэля Макрона в августе 2019 года о Большом переломе в Европейских и мировых цивилизационных процессах. Представлены основные идеи и направления Плана Великой Перезагрузки и осуществления четвертой промышленной революции Давосского Всемирного Экономического Форума (июнь, 2020).

Приведена содержательная хронология формирования организационного механизма внедрения инклюзивного капитализма и его руководящего и кадрового обеспечения. Рассмотрена равнозначность принципов гомеостаза экономических и биологических систем путем сопоставления восстановления живучести мировой сетевой экономики и морских биологических систем (на примере спрута-вампира).

Обобщены признаки международного и государственного терроризма в Украине. Обоснована необходимость изменения англосаксонской модели рыночной экономики открытого типа на социально-ориентированную с использованием доктрины трех "C": социальное прогнозирование, социальное планирование и социальное управление. Предложено использовать опыт США и Великобритании в отношении социального планирования и европейской финансовой модели народного капитализма.

На основе предложений О. С. Емельянова по повышению роли Центра во взаимодействии с Регионами рекомендуется разрабатывать Национальную и Региональные программы человеческого развития. Предлагается разработать Плановый кодекс Украины на положениях модели социально-адекватного менеджмента с энциклопедическими критериями их использования на национальном и региональных уровнях государственного управления.

Ключевые слова: менеджмент стратегирования, либеральная и плановая экономика, народный и инклюзивный капитализм, международный и государственный терроризм, бюджетный федерализм, региональное человеческое развитие, геополитическая напряженность, спрут-вампир, гегемон свободы.

Received by the editors: 18.12 .2020 and final form 29.12.2020 